\title{
Analisis Demand dan Supply Konsumsi Garam Beryodium Tingkat Rumah Tangga
}

\author{
Demand and Supply Analysis of Household Level Iodized Salt \\ Consumption
}

\author{
Nadia Irina Darmawan, Ede Surya Darmawan
}

Departemen Administrasi Kebijakan Kesehatan Fakultas Kesehatan Masyarakat Universitas Indonesia

\begin{abstract}
Abstrak
Secara nasional, konsumsi garam beryodium cukup adalah $62,3 \%$ dan di Provinsi Jawa Barat adalah 58,3\%. Cakupan konsumsi garam beryodium tingkat rumah tangga di Kota Bekasi hanya sekitar 62,14\%. Pemantauan garam beryodium di tingkat rumah tangga oleh Dinas Kesehatan Kota Bekasi tahun 2004 menunjukkan bahwa garam yang mengandung yodium cukup adalah $51 \%$. Penelitian ini dilakukan untuk mengetahui analisis faktor demand dan supply terhadap konsumsi garam beryodium tingkat rumah tangga di wilayah kerja Puskesmas Kecamatan Bekasi Barat Kota Bekasi dengan menggunakan desain cross sectional. Populasi yang diteliti yaitu 110 orang ibu dengan menggunakan uji chi square. Pada faktor demand didapatkan hasil bahwa ada hubungan pengetahuan dengan konsumsi garam beryodium tingkat rumah tangga. Namun, tidak ada hubungan antara pendapatan dengan konsumsi garam beryodium tingkat rumah tangga. Pada faktor supply didapatkan hasil bahwa tidak ada hubungan antara ketersediaan di pasar dan harga dengan konsumsi garam beryodium tingkat rumah tangga. Untuk meningkatkan cakupan konsumsi garam beryodium tingkat rumah tangga diperlukan kerja sama dari berbagai pihak.
\end{abstract}

Kata kunci: Garam beryodium, rumah tangga, demand, supply

\begin{abstract}
Nasionaly, the consumption of iodized salt is $62,3 \%$ and in Province of West Jawa is $58,3 \%$. The coverage consumption of iodezed in household level in Bekasi city only about $62,14 \%$. The monitoring iodezed salt in household level by district health departemen in 2004 showed that the enough iodezed salt is $51 \%$. This research was conducted to determine the factor analysis of demand and supply of iodized salt consumption at household level in the District of West Bekasi. This iodesed salt udy used cross sectional design. The population that was studied was 110 mothers using chi square test. On the demand factor, the result shows that there is a relationship between knowledge and the consumption of iodized salt at household level. However, there is no relationship between the revenue and the consumption of
\end{abstract}

iodized salt at household level. While in the supply factor, shows that there is no relationship between availability and price in the market and the consumption of iodized salt at household level. To improve the coverage of iodized salt consumption at household level, it is required cooperation from various parties.

Key words: lodized salt, household, demand, supply

\section{Pendahuluan}

Strategi jangka panjang yang lebih murah dan berkesinambungan adalah melakukan fortifikasi garam dengan yodium yang dikenal sebagai iodisasi garam. Penambahan yodium pada semua garam konsumsi telah disepakati sebagai cara yang aman, efektif, dan berkesinambungan untuk mencapai konsumsi yodium yang optimal bagi semua rumah tangga dan masyarakat. ${ }^{1}$ Tahun 2002, sidang United Nations General Assembly (UNGASS) telah menyepakati pembaharuan komitmen World Summit for Children tahun 1990 yaitu pencapaian eliminasi gangguan akibat kekurangan yodium (GAKY) dan universal salt iodization (USI) atau garam beryodium untuk semua berupa konsumsi garam beryodium 90\% secara berkesinambungan pada tahun 2005. Target yang ditetapkan dalam Indonesia Sehat adalah pencapaian USI pada tahun 2010. ${ }^{1}$ Sementara itu, target yang ditetapkan dalam Rencana Aksi Pembinaan Gizi Masyarakat tahun 2010-2014 adalah pencapaian USI pada tahun $2014 .^{2}$

GAKY di Indonesia merupakan salah satu masalah

Alamat Korespondensi: Ede Surya Darmawan, Departemen Administrasi Kebijakan Kesehatan FKM Universitas Indonesia, Gd. F Lt. 1 Kampus Baru UI Depok 16424, Hp.0811184713,e-mail: edesurya@ui.ac.id 
kesehatan masyarakat yang serius mengingat dampak yang sangat besar terhadap kelangsungan hidup dan kualitas sumber daya manusia. Berdasarkan hasil Riset Kesehatan Dasar (Riskesdas) tahun 2007 menunjukkan bahwa cakupan konsumsi garam yang mengandung cukup yodium $(\geq 30 \mathrm{ppm})$ masih jauh dari target USI $90 \%$. Cakupan konsumsi garam yang mengandung cukup yodium secara nasional sebesar $62,3 \%$ dan khusus di Provinsi Jawa Barat sebesar 58,3\%. ${ }^{3}$ Berdasarkan hasil survei garam beryodium di rumah tangga oleh Badan Pusat Statistik (BPS) pada tahun 2002 diperoleh data cakupan konsumsi garam beryodium tingkat rumah tangga di Kota Bekasi baru mencapai 62,14\%. Program pemantauan garam beryodium di tingkat rumah tangga yang dilakukan oleh Dinas Kesehatan Kota Bekasi pada tahun 2004 menunjukkan bahwa garam yang mengandung yodium cukup sebesar 51\%. ${ }^{4}$ Berdasarkan hasil pemantauan Dinas Kesehatan Kota Bekasi tahun 2004, kecamatan dengan cakupan konsumsi garam beryodium tingkat rumah tangga cukup rendah adalah Kecamatan Bekasi Barat yaitu 49,3\%. Tahun 2010, Dinas Kesehatan Kota Bekasi kembali melaksanakan program pemantauan garam beryodium di tingkat rumah tangga. Berdasarkan hasil pemantauan, Kecamatan Bekasi Barat merupakan kecamatan dengan cakupan konsumsi garam beryodium tingkat rumah tangga paling tinggi dibandingkan kecamatan lain di Kota Bekasi yaitu 84,6\%.5

Penelitian ini bertujuan untuk mengetahui hubungan faktor demand dan supply terhadap konsumsi garam beryodium tingkat rumah tangga di wilayah kerja Puskesmas Kecamatan Bekasi Barat Kota Bekasi tahun 2010.

\section{Metode}

Penelitian ini menggunakan desain cross sectional. Penelitian dilakukan pada bulan November tahun 2010 di puskesmas kelurahan yang terdapat di Kecamatan Bekasi Barat Kota Bekasi. Sampel dalam penelitian adalah ibu-ibu pengunjung puskesmas kelurahan dengan jumlah sampel sebanyak 110 orang. Teknik yang digunakan dalam pengambilan sampel adalah teknik pengambilan sampel secara kelompok (cluster sampling) dengan puskesmas kelurahan sebagai unit klaster. Kecamatan Bekasi Barat memiliki 5 puskesmas kelurahan sehingga terdapat 5 klaster. Sampel yang dibutuhkan adalah 110 orang sehingga setiap klaster akan diambil 22 sampel secara acak. Korelasi yang digunakan adalah uji chi square.

\section{Hasil}

\section{Konsumsi Garam Beryodium Tingkat Rumah Tangga}

Sebagian besar responden $(79,1 \%)$ sudah mengonsumsi garam beryodium, umumnya dalam bentuk garam halus $(94,5 \%)$. Sebagian besar responden $(82,7 \%)$ menggunakan garam dengan kategori merek garam yaitu garam beryodium. Garam beryodium yang biasa digunakan adalah garam dengan merek "Laba-Laba" (31,8\%), "Refina" (20\%), dan "Meja” (15,5\%).

\section{Faktor Demand}

Pada penelitian ini, yang dimaksud dengan faktor demand adalah pengetahuan dan pendapatan. Sebagian besar responden $(84,5 \%)$ mengetahui manfaat garam beryodium dan berpendapat bahwa manfaat garam beryodium hanya untuk mencegah gondok $(63,6 \%)$. Sebagian besar responden (90\%) berpendapat bahwa jumlah pendapatan tidak memengaruhi responden untuk mengonsumsi garam beryodium. Walaupun sebanyak $56,4 \%$ responden memiliki pendapatan kurang dari Rp. 1.000.000,- per bulan. Hasil analisis bivariat menunjukkan bahwa nilai $p=0,001$ sehingga dapat disimpulkan bahwa ada hubungan yang signifikan antara pengetahuan dengan konsumsi garam beryodium tingkat rumah tangga. Namun, tidak ada hubungan yang signifikan antara pendapatan dengan konsumsi garam beryodium tingkat rumah tangga (nilai $\mathrm{p}=0,468$ ).

\section{Faktor Supply}

Pada penelitian ini, ketersediaan garam beryodium dan harga di pasar merupakan faktor supply. Sebagian besar responden $(84,5 \%)$ berpendapat bahwa tidak sulit memperoleh garam beryodium karena $80,9 \%$ garam beryodium tersedia di pasar. Sebagian besar responden $(85,5 \%)$ berpendapat bahwa harga garam beryodium murah karena sebanyak $53,6 \%$ responden berpendapat harga yang beredar di pasaran Rp.1.000,- per bungkus. Dengan nilai $p=0,556$ dapat disimpulkan bahwa tidak ada hubungan yang signifikan antara ketersediaan garam beryodium di pasar dengan konsumsi garam beryodium tingkat rumah tangga. Harga garam beryodium juga tidak berhubungan signifikan dengan konsumsi garam beryodium di tingkat rumah tangga dengan nilai $p=1,000$.

\section{Pembahasan \\ Konsumsi Garam Beryodium Tingkat Rumah Tangga}

Konsumsi garam beryodium merupakan bagian dari komponen program pencapaian konsumsi garam beryodium untuk semua untuk mempercepat penurunan prevalensi GAKY. Garam konsumsi telah diakui sebagai solusi biaya yang paling efektif dan layak untuk mencegah dan mengontrol GAKY. ${ }^{6}$ Garam adalah bahan yang ideal untuk iodisasi karena semua manusia memerlukan garam dan terjangkau untuk hampir setiap orang. Jumlah garam yang masuk dalam tubuh sangat kecil, namun membuat suatu jenis makanan menjadi penting. Garam merupakan bumbu penting dalam masakan sehingga hampir seluruh responden menggunakan garam beryodium di rumah. Bentuk garam yang biasa digunakan di tingkat rumah tangga adalah garam halus. Sebanyak 
$68,82 \%$ garam yang ada di Indonesia merupakan garam halus. Garam halus memiliki kualitas yang lebih baik dibandingkan garam briket dan garam curai/krosok. ${ }^{1}$

\section{Faktor Demand}

Pengetahuan berkaitan dengan demand seseorang terhadap barang atau jasa. Fungsi permintaan juga mengasumsikan bahwa konsumen adalah yang paling baik informasinya tentang barang dan jasa yang akan dikonsumsi sehingga dialah orang yang paling tepat untuk memberikan penilaian. Berdasarkan informasi yang disebarkan, masyarakat kemudian terpengaruh untuk melakukan permintaan (demand) dan penggunaan (utilisasi) pelayanan kesehatan. ${ }^{7}$ Hasil penelitian ini sesuai dengan penelitian yang dilakukan oleh Chandranuringtyas, ${ }^{8}$ yang menyatakan bahwa ada hubungan yang bermakna antara pengetahuan dengan perilaku pada ibu rumah tangga terhadap penggunaan garam beryodium. Hasil serupa juga dinyatakan oleh Satori, ${ }^{9}$ bahwa ada hubungan antara tingkat pengetahuan dengan perilaku konsumsi kapsul minyak beryodium.

Selain manfaat, terdapat banyak hal yang berkaitan dengan garam beryodium seperti cara penyimpanan garam beryodium, cara membubuhkan garam beryodium ke dalam masakan, cara menguji kualitas garam beryodium di tingkat rumah tangga, dan lain sebagainya. Hal tersebut sebaiknya dapat dijelaskan oleh tenaga kesehatan puskesmas dalam penyuluhan atau pada saat dilakukan pemantauan garam beryodium tingkat rumah tangga. Penyampaian informasi yang jelas dapat meningkatkan pengetahuan masyarakat dan pada akhirnya meningkatkan cakupan konsumsi garam beryodium tingkat rumah tangga. Selain pengetahuan, pendapatan dapat memengaruhi jumlah permintaan. ${ }^{10}$ Pendapatan atau daya beli masyarakat merupakan faktor utama dalam konsumsi pangan. ${ }^{11}$

Hasil penelitian ini dapat dihubungkan dengan sifat perubahan permintaan (demand) apabila pendapatan berubah. Dalam ilmu ekonomi, berdasarkan sifat perubahan permintaan apabila pendapatan berubah, barang dapat dibedakan menjadi 4 golongan yaitu barang inferior, barang esensial, barang normal, dan barang mewah. ${ }^{10}$ Garam merupakan bumbu penting dalam masakan dan kebutuhan pokok masyarakat sehingga garam dapat dikelompokkan dalam barang esensial. Barang esensial yaitu barang yang sangat penting dalam kehidupan sehari-hari, tidak berubah walaupun pendapatan meningkat. Jenis makanan dengan kandungan yodium yang tinggi biasanya merupakan makanan yang dianggap mewah dan mahal oleh masyarakat. Dalam suatu masyarakat, meskipun telah terjadi peningkatan pendapatan, akan tetapi belum tentu akan berpengaruh atau tidak diikuti oleh peningkatan pengeluaran konsumsi pangan, khususnya pangan yang mempunyai kandungan gizi tinggi yang mengandung yodium. ${ }^{12}$

\section{Faktor Supply}

Keseimbangan dalam pasar terjadi ketika ada keseimbangan harga antara pembeli dan penjual. Harga adalah jumlah uang yang harus dibayar oleh konsumen untuk membeli suatu produk. Harga garam merupakan salah satu faktor yang memengaruhi keputusan konsumen untuk membeli garam beryodium. ${ }^{13}$ Hasil penelitian ini sesuai dengan penelitian yang dilakukan oleh Suraryo, ${ }^{13}$ yang menyatakan bahwa tidak ada hubungan antara harga garam beryodium dengan ketersediaan garam beryodium tingkat rumah tangga. Namun, jika dikaitkan dengan ketersediaan garam beryodium di pasar, ada hubungannya dengan konsumsi garam beryodium tingkat rumah tangga. Penelitian yang dilakukan oleh Rauf, 8 menyimpulkan bahwa ketersediaan garam beryodium berperan penting karena ketika produk tersedia di warung atau toko terdekat dari rumah konsumen atau tidak butuh waktu banyak untuk memperolehnya maka konsumen tidak akan mengubah pilihannya dari membeli garam beryodium menjadi garam biasa.

Hasil penelitian ini dapat dijelaskan dengan asumsi bahwa semakin banyaknya pasar-pasar tradisional dan nontradisional yang tersedia di sekitar tempat tinggal responden sehingga memudahkan responden memperoleh garam beryodium. Namun, garam-garam yang beredar di pasaran belum tentu mengandung cukup yodium. Program Garam Yodium Bergulir di Kecamatan Bekasi Barat juga memudahkan masyarakat memperoleh garam beryodium dengan harga yang terjangkau. Puskesmas dan posyandu menjual garam beryodium dengan harga murah yaitu Rp.1.000,- per bungkus. Hal ini menunjukkan bahwa ada upaya dari tenaga kesehatan untuk meningkatkan cakupan konsumsi garam beryodium tingkat rumah tangga di Kecamatan Bekasi Barat Kota Bekasi sehingga dapat mencapai target USI 90\% pada tahun 2014.

\section{Kesimpulan}

Sebagian besar responden $(79,1 \%)$ sudah mengonsumsi garam beryodium. Untuk faktor demand, sebanyak $84,5 \%$ responden mengetahui manfaat garam beryodium dan sebanyak $56,4 \%$ responden memiliki pendapatan kurang dari Rp.1.000.000,-.. Hasil analisis hubungan faktor demand menyatakan bahwa ada hubungan antara pengetahuan dengan konsumsi garam beryodium tingkat rumah tangga. Namun, tidak ada hubungan antara pendapatan dengan konsumsi garam beryodium tingkat rumah tangga. Untuk faktor supply, sebanyak $80,9 \%$ responden menyatakan garam beryodium tersedia di pasar dan sebanyak $85,5 \%$ responden menyatakan harga garam beryodium murah. Hasil analisis hubungan faktor supply menyatakan bahwa tidak ada hubungan antara 
ketersediaan garam beryodium di pasar dan harga garam beryodium dengan konsumsi garam beryodium tingkat rumah tangga.

\section{Saran}

Untuk berperan serta dalam pencapaian konsumsi USI pada tahun 2014, tenaga kesehatan di Puskesmas Kecamatan Bekasi Barat dapat melakukan pemantauan konsumsi garam beryodium tingkat rumah tangga melalui pengetesan kandungan garam secara berkesinambungan. Selain itu, tenaga kesehatan puskesmas dapat bekerja sama dengan kelompok-kelompok masyarakat dalam menyebarluaskan informasi mengenai hal-hal yang berkaitan dengan garam beryodium seperti cara penyimpanan garam beryodium, cara membubuhkan garam beryodium ke dalam masakan, cara menguji kualitas garam beryodium, dan lain sebagainya.

\section{Daftar Pustaka}

1. Kementerian Kesehatan Republik Indonesia. Pencegahan dan penanggulangan gangguan akibat kekurangan yodium (GAKY) di Indonesia. Jakarta: Kementerian Kesehatan Republik Indonesia; 2005.

2. Kementerian Kesehatan Republik Indonesia. Rencana aksi pembinaan gizi masyarakat 2010-2014. Jakarta: Kementerian Kesehatan Republik Indonesia; 2010.

3. Kementerian Kesehatan Republik Indonesia. Laporan hasil riset kesehatan dasar (riskesdas) Indonesia tahun 2007. Jakarta: Kementerian Kesehatan Republik Indonesia; 2008.

4. Dinas Kesehatan Kota Bekasi. Laporan. Bekasi: Dinas Kesehatan Kota
Bekasi; 2005.

5. Dinas Kesehatan Kota Bekasi. Laporan. Bekasi: Dinas Kesehatan Kota Bekasi; 2010.

6. Iodine deficiency disorders and universal salt iodisation: South Asia priorities. [diakses tanggal 3 Desember 2010]. Diunduh dari: http:// www.unicef.org.

7. Tjiptoherijanto P, Soesetyo B. Ekonomi kesehatan. Jakarta: Rineka Cipta; 2008.

8. Chandranuringtyas H. Faktor-Faktor yang berhubungan dengan perilaku ibu rumah tangga terhadap penggunaan garam beryodium sebagai salah satu upaya pencegahan GAKY di Kelurahan Sukmajaya Depok tahun 2003 [skripsi]. Depok: Fakultas Kesehatan Masyarakat Universitas Indonesia; 2003.

9. Satori TA. Faktor-faktor yang berhubungan dengan konsumsi kapsul minyak beryodium pada wanita usia subur (WUS) di 5 kecamatan endemik GAKY berat dan sedang tahun 2003 [skripsi]. Depok: Fakultas Kesehatan Masyarakat Universitas Indonesia; 2004.

10. Sukirno S. Mikro ekonomi teori pengantar. Jakarta: PT Raja Grafindo Persada; 2008.

11. Martianto D, Ariani M. Analisis perubahan konsumsi dan pola konsumsi pangan masyarakat dalam dekade terakhir. Prosiding Widyakarya Nasional Pangan dan Gizi VII, Ketahanan Pangan, dan Gizi di Era Otonomi Daerah dan Globalisasi; 17-19 Mei 2004; Jakarta.

12. Soeharyo. Aspek sosio-kultural pada program penanggulangan GAKY. Jurnal GAKY Indonesia. 2002; 1 (1).

13. Suraryo YT. Gambaran faktor-faktor yang mempengaruhi ketersediaan garam beryodium tingkat rumah tangga di Kabupaten Tapin Provinsi Kalimantan Selatan tahun 2002 [skripsi]. Depok: Fakultas Kesehatan Masyarakat Universitas Indonesia; 2002. 